\title{
Diet in Chronic Kidney Disease: an integrated approach to nutritional therapy
}

\author{
(iD) Raíssa Antunes Pereira ${ }^{1}$ \\ (D) Christiane Ishikawa Ramos ${ }^{2}$ \\ (D) Renata Rodrigues Teixeira ${ }^{1}$ \\ (D) Gisselma Aliny Santos Muniz² \\ (iD) Gabriele Claudino² \\ (iD) Lilian Cuppari, 1,3
}

\begin{abstract}
1. Programa de Pós-Graduação em Nutrição, Universidade Federal de São Paulo - Escola Paulista de Medicina, São Paulo, SP, Brasil 2. Programa de Pós-Graduação em Nefrologia, Disciplina de Nefrologia, Universidade Federal de São Paulo - Escola Paulista de Medicina, São Paulo, SP, Brasil 3. Fundação Oswaldo Ramos - Hospital do Rim, São Paulo, SP, Brasil
\end{abstract}

\section{SUMMARY}

A healthy diet is an essential requirement to promote and preserve health, even in the presence of diseases, such as chronic kidney disease (CKD). In this review, nutritional therapy for CKD will be addressed considering not only the main nutrients such as protein, phosphorus, potassium, and sodium, which require adjustments as a result of changes that accompany the reduction of renal functions, but also the benefits of adopting dietary patterns associated with better outcomes for both preventing and treating CKD. We will also emphasize that these aspects should also be combined with a process of giving new meaning to a healthy diet so that it can be promoted. Finally, we will present the perspective of an integrated approach to the individual with CKD, exploring the importance of considering biological, psychological, social, cultural, and economic aspects. This approach has the potential to contribute to better adherence to treatment, thus improving the patient's quality of life.

KEYWORDS: chronic kidney disease, diet, nutrition, dialysis

\section{INTRODUCTION}

Proper nutrition is a basic requirement to promote and preserve health and is recognized as a determinant and conditioning factor for the health status of individuals and groups of people. In situations of chronic diseases, such as chronic kidney disease (CKD), diet is part of its treatment at all stages. Changes in lifestyle that include the practice of physical exercise, proper nutrition, and smoking cessation are important factors that, when associated with the control of blood pressure, blood glucose, and lipid profile, contribute to decrease the rate of progression of
CKD. More recently, the approaches used to advise patients with CKD regarding diet have been discussed because of the difficulty in getting patients to adhere to the recommendations. ${ }^{1}$ Furthermore, studies suggest that greater attention should be given to the quality of these patients' diets. ${ }^{2.3}$ At the same time, the concept of a healthy diet has been discussed, and the need to give it a new meaning has become evident. ${ }^{4.5}$ Due to the relevance of diet as part of any stage of the CKD treatment, it is necessary for health professionals who handle with CKD patients to have a basic 
understanding of what is a healthy diet, regardless of their area of specialization. In this context, to clearly delineate the concept of a healthy diet, it is necessary to take a closer look into history.

\section{Healthy diet in CKD: giving it a new meaning to promote it}

Historically, the concept of a healthy diet has been tied to an almost exclusively biological perspective of eating, often associated with the metabolism, digestion, absorption, and storage of nutrients (post-swallowing aspects). To Viana et al., ${ }^{6}$ we excessive rationalize the diet and nutritional process, reducing it to the physicalist perspective of nutrients and its influence on the body. The American gastronomic critic Steingarten ${ }^{7}$ stated that "health authorities never consider the profound benefits that delicious food can bring to our miserable lives. In over 1,000 pages of federal reports on nutrition, I could not find a single occurrence of the words delicious, tasty, or flavorful.”. In addition, this reductionist outlook on nutrition contributed to Nutritionism, which identifies food items just as the sum of its nutrients, minimizing or even excluding the sociocultural components of food and commensality, transforming nutrition into an exact and purely biological science. ${ }^{8}$ However, eating is a complex process that, when seen only by this perspective, ignores the various determinants of food choices, which include interactions of factors related to food, the environment, and the individual including their own subjectivity. ${ }^{9}$ Although satisfying nutritional needs is essential for survival, the meanings of food should not be understood only by means of nutritional indicators. Eating and sharing food ensures both our physiology as our humanity, because what you eat, how and when you eat it, are elements filled with meaning. ${ }^{6}$ In this sense, considering pre-swallowing aspects, i.e., behavior, culture, society, and experiences around food, it is essential to understand and recommend a healthy diet. In fact, if we think that knowledge-based choices represent very little compared to the diverse influences that operate below the level of consciousness, we could say that focusing only on biological aspects is counterproductive. ${ }^{10}$ As an example, just see how efforts to curb obesity rates have not shown good results; coincidently, they are often focused only on the biological aspects of nutritions and health.

On the other hand, studies about the so-called "French paradox" show that there are substantial differences in the dietary beliefs and concerns among countries. Attitudes such as spending more time eating; having more social moments around food; seeing food as a source of pleasure, not of guilt or concern; eating fresher food (regardless of nutrients), and relying on internal cues from the body to decide how much to eat, are among the main characteristics that differentiate the relationship of French and American individuals with food. However, the French have better health parameters than Americans. ${ }^{13-16}$ When commenting on these results, Pollan ${ }^{17}$ suggests, paradoxically, that considering food more than an end to bodily health, i.e., as also a source of pleasure, socialization, and identity, does not make people less healthy; in fact, there are reasons to believe that this could make them healthier. Thus, it is worth questioning: to those of which of the two countries (France or the United States) do our practices resemble?

In this sense, the most recent version of the Dietary Guideline for the Brazilian Population ${ }^{18}$ represents a paradigm disruption in the dissemination and definition of a healthy diet, bringing in its chapters the importance of eating as a social activity and also of having pleasure from it. The Brazilian Guideline considers, as a principle, the need to promote the individual's autonomy regarding their diet and stresses that adopting a healthy diet is not merely a matter of individual choice, since several factors, such as the physical, economic, political, cultural, or social nature can positively or negatively influence the dietary patterns of individuals. The Guideline classifies foods into categories according to the processing level employed in their production (in natura or minimally processed food, processed food, and ultra-processed food), instead of their content of nutrients. Table 1 describes ten steps to a healthy diet, according to the Guideline.

In addition to the questions raised, to optimize the promotion of a healthy diet, it is necessary to have a better understanding of the individual's belief system, because the way we think about "food" and "healthy" predicts our eating behavior ${ }^{19}$. In a qualitative study, Kelly et al. ${ }^{20}$ listened to patients with CKD in order to understand their experiences in relation to the dietary approaches employed. The patients reported a lack of support and regular feedback to sustain changes, that the guidelines provided do not consider the promotion of dietary autonomy, and that the ambiguity of information between health professionals, and the dichotomization of foods, as in 'allowed' and 'not allowed', 'good' and 'bad', contributes to making 
them feel exasperatedly unable to adhere to the guidelines. Thus, patients value professionals who transmit tranquility, are positive, involve their families and/or caregivers, and focus on what is possible in their diet, and not on imposing restrictions ${ }^{20}$. In addition, it is necessary to have caution because extremely restrictive approaches with CKD patients can contribute to worsening diet quality ${ }^{2}$.

Improving communication skills with patients is another step to improve adherence to nutritional therapy. ${ }^{21.22}$ Simply sharing various nutritional information is not enough to change the patient's behavior and promote adherence, especially in the long term. ${ }^{23}$ However, as already mentioned, it is first essential to understand "healthy" more broadly, and then move on to strategies. Considering the above, it is prudent to say that there cannot be a definition of what is a healthy eating without contextualizing "who, when, how, and where". Finally, in the presence of chronic diseases, the essence of any health intervention needs to be the individual, valuing, therefore, their subjectivity, culture, social, and economic aspects. Similarly, in the CKD, regardless of its stage, all these factors must be considered. The adjustments of some nutrients that require special care in CKD, such as protein, phosphorus, potassium, and sodium, will be discussed in this chapter and must be performed without disregarding the global nature of healthy eating.

\section{PROTEIN}

The control of the amount of protein has been one of the most discussed dietary practices in CKD. The acute ingestion of proteins influences the renal hemodynamics, increases the renal plasma flow, the intraglomerular pressure, and glomerular filtration rate. This physiological effect aims to increase the excretion of products derived from the protein metabolism through the kidneys. ${ }^{24}$ In healthy individuals, a high intake of protein in the long-term does not seem to promote deleterious effects on renal function; however, increased protein intake was associated with a lower glomerular filtration rate (GFR) in individuals with some degree of CKD. ${ }^{25}$ In this sense, it is suggested that the popular high-protein diets, used for various purposes, should be used with caution, since CKD is a silent condition, commonly underdiagnosed and of growing incidence.

Considering that glomerular hyperfiltration is one of the pathophysiological mechanisms of CKD progression, low-protein diets ( 0.6 to $0.8 \mathrm{~g} / \mathrm{kg} /$ day) have become popular as a dietary strategy in the non-dialysis stage. However, its benefit on the progression of CKD remains controversial, particularly after the widespread use of renin-angiotensin-aldosterone system (RAAS) inhibitors. ${ }^{26}$ However, this strategy presents important benefits on the reduction of proteinuria and the need for dialysis. ${ }^{27}$ Low-protein diet also contributes to reducing the endogenous production and accumulation of toxic metabolites, attenuating clinical manifestations of uremia. In addition, nutrients such as phosphorus, potassium, saturated fatty acids, sodium, and acid-producing compounds, are present in the main sources of protein, such as meats in general, eggs, and dairy products. ${ }^{28}$ Thus, reduced ingestion of these foods helps in the prevention and treatment of eletrolyte, metabolic, and hormonal disorders in CDK. Recently, the short term reduction of protein intake, was accompanied by a decrease in serum concentrations of toxins from the intestinal microbiota. ${ }^{29.30}$ Despite the benefits mentioned above, there are concerns that low-protein diets may promote malnutrition. However, to date, studies have not found any significant changes in

TABLE 1. TEN STEPS TO A HEALTHY DIET ACCORDING TO THE DIETARY GUIDELINE FOR THE BRAZILIAN POPULATION ${ }^{18}$.

\begin{tabular}{|l|}
\hline 1. Make in natura or minimally processed foods the foundation of the diet. \\
\hline 2. Use oils, fats, salt, and sugar in small amounts to season and cook food and create culinary preparations. \\
\hline 3. Limit the consumption of processed foods. \\
\hline 4. Avoid the consumption of ultra-processed foods. \\
\hline 5. Eat regularly and thoughtfully, in appropriate environments and, whenever possible, with company. \\
\hline 6. Shop at places that offer a variety of in natura or minimally processed foods. \\
\hline 7. Develop, exercise, and share culinary skills. \\
\hline 8. Planning time to give eating the space it deserves. \\
\hline 9. Give preference, when away from home, to places that serve fresh meals. \\
\hline 10. Be critical about the information, guidance, and messages on nutrition published in commercial advertisements. \\
\hline
\end{tabular}


the nutritional status of CKD patients on low-protein diets. ${ }^{31}$ However, it is necessary to monitor nutritional status and energy intake.

In addition to the quantity, the influence of the type of protein on renal function is also discussed in the non-dialysis stage of CKD. Population-based prospective studies have observed a direct relationship between the intake of red meat, the incidence of $\mathrm{CKD},{ }^{32,33}$ and the need of dialysis. ${ }^{34}$ Although these data indicate a possible advantage of replacing red by white meat, intervention studies with this purpose are scarce. In cross-over and randomized clinical trials, the replacement of red meat by chicken with the same amount of protein $(1.4 \mathrm{~g} / \mathrm{kg} /$ day $)$ decreased proteinuria in patients with diabetes mellitus type 2 ; the reduction was even greater with an ovo-lacto vegetarian low-protein $\operatorname{diet}(0.7 \mathrm{~g} / \mathrm{kg} / \mathrm{day}))^{35,36}$ In the same way, replacing animal protein for plant-based protein sources, particularly soybeans, without changing the total quantity of the nutrient, showed no positive impact on the GFR. ${ }^{37}$ Thus, the benefits of controlling dietary protein at the non-dialysis stage of CKD is more related to the adjustment of the quantity than of the type of protein.

Clinical guidelines suggest a diet with 0.8 to $1.0 \mathrm{~g} /$ $\mathrm{kg} / \mathrm{day}$, in stages 1 and 2 and, 0.6 to 0.8 in stages 3 and $4 .^{38} \mathrm{~A}$ more marked restriction $(0.3$ to $0.4 \mathrm{~g} / \mathrm{kg} /$ day) supplemented with keto-analogues and essential amino acids can also be employed in patients with GFR $<30 \mathrm{~mL} / \mathrm{min} / 1.73 \mathrm{~m} 2 .{ }^{39}$ Despite the numerous benefits demonstrated with the use of keto-analogues, this approach has great difficulty of implementation due to its strict food restriction, high cost, high number of pills, among others. ${ }^{39}$ For dialysis patients, higher protein content is recommended (1.1 to $1.3 \mathrm{~g} / \mathrm{kg} /$ day), due to the higher degree of protein catabolism and losses of amino acids/peptides in hemodialysis (HD), or proteins in peritoneal dialysis. ${ }^{38}$ Providing healthy meals before, during, and after a dialysis session may attenuate the protein catabolism. ${ }^{40}$

\section{PHOSPHORUS}

The adjustment in the phosphorus intake is among the dietary-therapeutic objectives in CKD, especially in cases of hyperphosphatemia. However, it is important to emphasize that the prevention and treatment of hyperphosphatemia involve a multidisciplinary approach since its cause is multifactorial and includes the insufficient phosphorus removal by dialysis, use of vitamin D analogs, bone and mineral metabolism disorders, and the inappropriate use of phosphorus binders agents. ${ }^{41}$

Phosphorus is found in a wide variety of foods, in organic and inorganic forms. Organic phosphorus is found naturally, especially in foods that are sources of protein, both vegetable (legumes and nuts) or animal. However, the phosphorus content of animal-based foods is more easily absorbed by the gastrointestinal tract (GIT) than that of vegetable origin $(>70 \%$ vs. < $40 \%$, respectively). In plants, part of the phosphorus is complexed to the phytate (carbohydrate not digested by the GIT enzymes), impairing the absorption of this mineral. Inorganic phosphorus, whose absorption by the GIT may reach $100 \%$, is found in the form of chemical additives used in many processed and ultra-processed foods. ${ }^{42.43}$ The intake of these foods has increased in recent decades, which can contribute to excessive intake of phosphorus in the general population and phosphorus overload in CKD. ${ }^{44}$ The following topics describe some dietary strategies to decrease phosphorus intake.

\section{ORGANIC PHOSPHORUS}

In the early stages of CKD, the adjustment of protein intake also contribute to reduce phosphorus intake. ${ }^{45}$ Although hyperphosphatemia is more prevalent in advanced stages, reducing phosphorus overload by dietary control in the earlier stages can help prevent or delay the development of secondary hyperparathyroidism. ${ }^{46}$

In HD, due to the increased protein need, strategies that promote the adequate intake of proteins with lower phosphorus content are required. There is evidence of lower mortality in patients with high protein intake and low serum phosphate, in comparison to those with high levels of both. ${ }^{47}$ Thus, encouraging the intake of foods with lower phosphorus-to-protein ratio (Table 1) can be a good strategy. Although there is no recommendation regarding the ideal ratio, higher mortality was observed with a daily intake greater than $16 \mathrm{mg}$ of phosphorus per gram of protein. ${ }^{48}$

\section{INORGANIC PHOSPHORUS}

In Brasil, despite the description of additives on food labels, there is no obligation to inform the amount of phosphorus present in food, which makes it difficult to estimate its intake. ${ }^{49}$ In a North American 
study, authors found approximately $40 \%$ more phosphorus in foods and menus with phosphorus-based additives in comparison to those without additives. ${ }^{50}$ Foods containing phosphorus-based additives frequently consumed by patients undergoing HD are: processed meats, bacon, restructured meats (e.g., nuggets ${ }^{\circledR}$, hamburgers), some yogurts, UHT milk, processed cheeses, instant noodles, cookies, cake mixes, and juice powder..$^{51.52}$ The additives most commonly used are phosphoric acid, sodium diphosphate, and tricalcium phosphate. ${ }^{51}$ After evaluating the influence of foods sources of organic or inorganic phosphorus on the phosphatemia of patients under HD, only inorganic phosphorus was associated with hyperphosphatemia. ${ }^{52}$

Thus, encouraging greater consumption of in natura and minimally processed foods, instead of processed ones, is a good strategy to control phosphatemia. This also contributes to the reduction of sodium intake and improves dietary quality. A controlled clinical trial showed a reduction of serum phosphorus of HD patients with persistent hyperphosphatemia, when instructed to replace foods with phosphorus additives by similar types of food without them. ${ }^{51}$ Therefore, strategies should consider the individuality of each patient.

In addition to the diet, the use of phosphorus binder agents (when necessary) may contribute to reduce serum phosphorus. The binders should be used during meals, in an amount proportional to the phosphorus content of the food ${ }^{41}$.

\section{POTASSIUM}

The adjustment of the potassium intake also deserves attention in CKD, particularly in the more advanced stages, due to the higher prevalence of hyperkalemia. ${ }^{53}$ Besides the reduced renal excretion, other factors contribute to the increase of serum potassium, such as metabolic acidosis, intestinal constipation, diabetes mellitus, use of RAAS inhibitors, beta-blockers, potassium-sparing diuretics, and food intake. Thus, all these factors must be considered to prevent and treat hyperkalemia. ${ }^{53}$

Potassium is found in a wide variety of foods, both animal (meat and dairy) and plant-based, such as fruits, vegetables, legumes, and nuts are its main sources. However, it is important to point out that plant-based foods should not be excluded from the diet since they are also sources of vitamins, minerals,

TABLE 1. PHOSPHORUS-TO-PROTEIN RATIO IN USUAL PORTIONS OF FOOD ${ }^{48}$

\begin{tabular}{|c|c|c|c|c|c|}
\hline Food & $\begin{array}{l}\text { Amount } \\
\text { (g) }\end{array}$ & Usual portion & $\begin{array}{l}\text { Phosphorus } \\
\text { (mg) }\end{array}$ & $\begin{array}{l}\text { Protein } \\
\text { (g) }\end{array}$ & $\begin{array}{l}\text { Ratio phosphorus/ } \\
\text { protein (mg/g) }\end{array}$ \\
\hline \multicolumn{6}{|l|}{ Meat and eggs } \\
\hline Chicken & 80 & 1 medium breast fillet & 150 & 23.0 & 6.5 \\
\hline Pork & 80 & 1 medium pork chop & 147 & 21.2 & 6.9 \\
\hline Beef & 85 & 1 medium steak & 209 & 26.0 & 8.0 \\
\hline Whitefish & 84 & 1 medium fillet & 241 & 20.6 & 11.7 \\
\hline Beef liver & 85 & 1 medium steak & 404 & 22.7 & 17.8 \\
\hline Sardine & 34 & 1 unit & 170 & 8.4 & 20.2 \\
\hline Whole egg & 50 & 1 unit & 90 & 6.0 & 15 \\
\hline \multicolumn{6}{|l|}{ Sausages } \\
\hline Sausage* $^{*}$ & 60 & 1 unit & 126 & 13.9 & 9.1 \\
\hline $\operatorname{Ham}^{\star}$ & 48 & 2 medium slices & 136 & 14 & 9.7 \\
\hline \multicolumn{6}{|c|}{ Milk and dairy products } \\
\hline Cheese & 30 & 2 thin slices & 153 & 7.5 & 20.4 \\
\hline Requeijão* & 30 & 1 tablespoon & 134 & 2.9 & 46.2 \\
\hline Natural yogurt & 120 & 1 small cup & 159 & 6.3 & 25.2 \\
\hline UHT milk* & 150 & 1 glass & 140 & 4.9 & 28.6 \\
\hline \multicolumn{6}{|c|}{ Legumes and nuts } \\
\hline Cooked beans & 154 & 1 medium ladle & 133 & 6.9 & 19.3 \\
\hline Peanuts & 50 & 1 small package & 253 & 13 & 19.5 \\
\hline
\end{tabular}

* may contain phosphorus-based additives. 
and bioactive compounds. In addition, these foods may contribute indirectly to the control of hyperkalemia. Studies carried out in patients not on dialysis and with normal serum potassium found that the increased intake of fruits and vegetables had the same effect on correcting metabolic acidosis as the standard treatment with sodium bicarbonate, without inducing hyperkalemia. ${ }^{54.55}$ There is no evidence regarding this strategy in the dialysis stage. In addition, the higher intake of fibers provided by these foods is associated with the regulation of bowel transit, and may increase fecal excretion of potassium. Thus, the assessment of diet intake is essential to achieve the proper adjustment of dietary potassium, taking into account patients' culture, habits, preferences, and the variety of foods needed to ensure the dietary quality and the intake of other nutrients. The following topics describe strategies to control potassium intake.

\section{Selection of food based on the potassium con-} tent

There are no specific recommendations about the amount of potassium that CKD patients, with or without hyperkalemia, should ingest. In addition, the definition of food as "rich" or "poor" in potassium. In clinical practice, estimation of potassium intake is challenging because of the limited information regarding the potassium content in food composition tables, the non-obligation to declare it on the label of products, in addition to the difficulty in estimating portions due to the variations in the sizes of food and household utensils, and the subjectivity of the definition of portion (e.g., what is an "average unit of fruit?"). Thus, dietary advices should be individualized and focused on promoting autonomy for choosing or combining foods and stimulating changes within the patients' dietary repertoire. ${ }^{56}$

Cooking technique for reducing potassium in plant-based foods

Cooking vegetables in water is a good strategy to reduce the potassium content of food, which enables the maintenance of this important food group in the diet. Although some centers still employ the technique of cooking plant-based foods in water twice, there is evidence that the largest mineral loss occurs during the first cooking. ${ }^{57}$ Thus, it is indicated to cook plant-based foods only once in abundant water, discarding the cooking water to remove part of the potassium content. In this procedure facilitates the preparation, and minimizes the loss of flavor and consistency, improving the acceptance and pleasure in eating. ${ }^{57}$ Studies have also evaluated the technique of soaking, which was not efficient in removing the potassium content of foods. ${ }^{57.58} \mathrm{It}$ is noteworthy that not all plant-based foods need to be cooked, but it is important to evaluate the overall context of the diet so that the inclusion of raw vegetables does not contribute to hyperkalemia.

\section{Attention to potassium additives}

Many additives found in processed foods are potassium-based, and have greater absorption by the GIT than potassium naturally found on foods. ${ }^{59}$ Sherman and Mehta ${ }^{60}$ analyzed the amount of potassium additives in processed meats and observed an amount of potassium up to three times higher in comparison to "fresh" meat. The commonly used additives are potassium sorbate, potassium citrate, and potassium diphosphate ${ }^{60}$. In addition, potassium chloride has also been widely used to replace sodium chloride to reduce sodium in the diet, either in the form of "light" salt or in food products described as with reduced sodium content. Therefore, nutritional education that stimulates reducing the intake of processed foods can also be interesting for serum potassium control.

\section{Sodium}

As in the general population, the sodium intake in CKD patients is high, and several benefits from the reduction of this mineral have been reported. In the non-dialysis stage, studies show that reducing the intake of sodium potentiates the action of antihypertensive drugs and decreases blood pressure and proteinuria. ${ }^{61.62}$ In HD, the adjustment of sodium intake contributes to lower interdialytic weight gain, which, in turn, is associated with better clinical outcomes. ${ }^{63}$ The dietary challenges to adjust the sodium intake consist not only in reducing the consumption of processed foods but also of sodium chloride and artificial seasonings used to prepare meals. Therefore, in addition to patient-centered strategies that seek the use of natural foods and seasonings, there is also a need for public policies that aim to simplify information found on food labels and to promote greater consumption of in natura and minimally processed food, so that it is possible to reduce sodium intake. ${ }^{64}$ Such measures would be in line with the Dietary Guidelines for the Brazilian Population mentioned before. ${ }^{18}$ 


\section{Dietary Patterns and Chronic kidney Disease}

For a long time, research in nutrition has focused on isolated nutrients, which does not portray the complexity of food choices and the wide dietary variety of a meal or eating habit. In addition, the biological effects of an isolated nutrient can be altered by its interaction with other components of the same food or other foods in the diet. Thus, a global analysis of the diet or eating patterns enables to capture the potential synergy between food and nutrients, in addition to allowing more adequate dietary comparisons between different population groups.

The modern lifestyle has led to important changes in dietary patterns, especially in western societies, characterized by excessive consumption of red meat, refined grains, dairy products, soft drinks, fried foods, and processed products. ${ }^{65}$ This pattern has been associated with an increased risk for weight gain, cardiovascular complications, mortality due to cardiovascular diseases (CVD), and cancer. ${ }^{66-68}$ On the other hand, dietary patterns with a higher contribution of in natura or minimally processed plant-based foods, and less animal-based and processed ones, have been associated with a lower risk for type 2 diabetes mellitus, obesity, CVD, CKD, and all-cause mortality. ${ }^{69-71}$ In addition to the effects on health, patterns based in plantbased foods are more environmentally sustainable, compared to those rich in animal-based products. ${ }^{72}$ It is important to emphasize that we are not encouraging a vegetarian or vegan diet, since a moderate consumption of poultry, fish, and dairy products does not seem to bring adverse consequences to health. ${ }^{72}$

In $\mathrm{CKD}$, the findings point out to the same direction. A meta-analysis showed that, in general, patterns based in plant-based foods and with a smaller presence of meat, especially red, salt, and refined sugar was associated with lower mortality. ${ }^{73}$ Recently, in patients in stages 3 and 4 of CKD, an adequate intake of fruits and vegetables, combined or not to other health behaviors, was associated with lower mortality and a delay in the progression of the disease. ${ }^{74}$

\section{FINAL CONSIDERATIONS}

The act of eating is immersed in a wide and varied collection of cultural practices that interact with the subjectivity of each individual; therefore, understanding them is essential to draw better strategies for nutritional therapy. In addition, adjustments in the intake of nutrients, such as protein, phosphorus, potassium, and sodium, all common in the treatment of CKD, should be performed considering the global context of the diet, in order to ensure quality. The Dietary Guidelines for the Brazilian population can be used as a tool to guide dietary strategies in CKD since it promotes the consumption of foods with less processed foods, hence helping out the control of phosphorus, sodium, and potassium. In addition, the guidelines also encourages a broader look on a diet by proposing a rediscovery of culinary practices and commensality and criticizes the aspects involved in the purchasing and advertising of foods.

In the integrative care of the patient, it is urgent to consider the individual besides the disease and the diet beyond nutrients. Thus, it is important that health professionals, regardless of the area, reflect on their own beliefs and relationship to food in order to improve patients'care in the promotion of healthy eating. Finally, more studies are needed to assess different strategies to promote dietary behavior change, particularly in patients with CKD in less advanced stages, in order to prevent the various complications associated with the disease.

\section{Conflict of interest}

The authors declare there are no conflicts of interest.

\section{Contribution of the authors}

All authors contributed to the drafting and final revision of the article.

\section{RESUMO}

Uma dieta saudável é essencial para promover e preservar a saúde, mesmo na presença de doenças como a Doença Renal Crônica (DRC). Nesta revisão, a terapia nutricional para pacientes de DRC será abordada levando em conta não só os principais nutrientes que precisam ser ajustados devido às alterações que acompanham a redução das funções renais, tais como proteínas, fósforo, potássio e sódio. Abordaremos também os benefícios da adoção de padrões alimentares associados a desfechos melhores tanto para a prevenção quanto para o tratamento da DRC. Também enfatizaremos que esses aspectos devem ser aliados a um processo de ressignificação do conceito de dieta saudável para que seja possível a sua promoção. Por último, apresentaremos a perspectiva de uma abordagem integrada para o indivíduo com DRC, explorando a importância de considerar aspectos biológicos, psicológicos, sociais, culturais e econômicos. Essa abordagem tem o potencial de contribuir para uma melhor adesão ao tratamento, melhorando assim a qualidade de vida do paciente.

PALAVRAS CHAVE: Terapia nutricional. Alimentação. Insuficiência renal crônica. 


\section{REFERENCES}

1. Lambert K, Mullan J, Mansfield K. An integrative review of the methodology and findings regarding dietary adherence in end stage kidney disease. BMC Nephrol. 2017;18(1):318

2. Fernandes $A S$, Ramos $\mathrm{CI}$, Nerbass FB, Cuppari L. Diet quality of chronic kidney disease patients and the impact of nutritional counseling. I Ren Nutr. 2018;28(6):403-10.

3. Martins AM, Bello Moreira AS, Canella DS, Rodrigues J, Santin F, Wanderley $B$, et al. Elderly patients on hemodialysis have worse dietary quality and higher consumption of ultraprocessed food than elderly without chronic kidney disease. Nutrition. 2017;41:73-9.

4. Leeman RF, Fischler C, Rozin P. Medical doctors' attitudes and beliefs about diet and health are more like those of their lay countrymen (France, Germany, Italy, UK and USA) than those of doctors in other countries. Appetite. 2011;56(3):558-63.

5. Silva DO, Recine EGIG, Queiroz EFO. Concepções de profissionais de saúde da atenção básica sobre a alimentação saudável no Distrito Federal, Brasil. Cad Saúde Pública. 2002;18(5):1367-77.

6. Viana MR, Neves AS, Camargo Junior KR, Prado SD, Mendonça ALO. A racionalidade nutricional e sua influência na medicalização da comida no Brasil. Ciênc Saúde Coletiva. 2017;22(2):447-56.

7. Steingarten J. O homem que comeu de tudo. São Paulo: Companhia das Letras; 2003. 496p.

8. Scrinis G. Functional foods or functionally marketed foods? A critique of, and alternatives to, the category of "functional foods." Public Health Nutr. 2008;11(5):541-5.

9. Sobal J, Bisogni CA, Jastran M. Food choice is multifaceted, contextual, dynamic, multilevel, integrated, and diverse. Mind Brain Educ. 2014;8(1):6-12

10. Mennucci L, Timerman F, Alvarenga M. Como a subjetividade infuencia o comportamento alimentar? In: Alvarenga MS, Antonaccio C, Figueiredo M, Timerman F, eds. Nutrição comportamental. 2a. ed. Barueri: Manole; 2019.

11. Malta DC, Oliveira TP, Santos MAS, Andrade SSCA, Silva MMA. Avanços do plano de ações estratégicas para o enfrentamento das doenças crônicas não transmissíveis no Brasil, 2011-2015. Epidemiol Serv Saúde. 2016;25(2):373-90

12. Miller WC. How effective are traditional dietary and exercise interventions for weight loss? Med Sci Sports Exerc. 1999;31(8):1129-34.

13. Drewnowski A, Henderson SA, Shore AB, Fischler C, Preziosi P, Hercberg S. Diet quality and dietary diversity in France: implications top the French paradox. . Am Diet Assoc. 1996;96(7):663-9.

14. Rozin P, Fischler C, Imada S, Sarubin A, Wrzesniewski A. Attitudes to food and the role of food in life in the U.S.A., Japan, Flemish Belgium and France: possible implications for the diet-health debate. Appetite. 1999;33(2):163-80

15. Rozin P, Kabnick K, Pete E, Fischler C, Shields C. The ecology of eating: smaller portion sizes in France than in the United States help explain the French paradox. Psychol Sci. 2003;14(5):450-4.

16. Wansink B, Payne CR, Chandon P. Internal and external cues of meal cessation: the French paradox redux? Obesity (Silver Spring). 2007;15(12):2920-4

17. Pollan M. Em defesa da comida. Rio de Janeiro: Intrinseca; 2008. 272p.

18. Brasil. Ministério da Saúde. Secretaria de Atenção à Saúde. Departamento de Atenção Básica. Guia alimentar para a população brasileira [Internet]. Brasília; 2014. [cited 2019 Sep 8]. Available from: http://bvsms.saude.gov. $\mathrm{br} /$ bvs/publicacoes/guia_alimentar_populacao_brasileira_2ed.pdf

19. Falk LW, Sobal J, Bisogni CA, Connors M, Devine CM. Managing healthy eating: definitions, classifications, and strategies. Heal Educ Behav. 2001;28(4):425-39

20. Kelly JT, Campbell KL, Hoffmann T, Reidlinger DP. Patient experiences of dietary management in chronic kidney disease: a Focus Group Study. J Ren Nutr. 2018;28(6):393-402.

21. Desroches S, Lapointe A, Ratté S, Gravel K, Légaré F, Turcotte S. Interventions to enhance adherence to dietary advice for preventing and managing chronic diseases in adults. Cochrane Database Syst Rev. 2013;(2):CD008722.

22. Beto JA, Schury KA, Bansal VK. Strategies to promote adherence to nutritional advice in patients with chronic kidney disease: a narrative review and commentary. Int | Nephrol Renovasc Dis. 2016;9:21-33.

23. Durose CL, Holdsworth M, Watson V, Przygrodzka F. Knowledge of dietary restrictions and the medical consequences of noncompliance by patients on hemodialysis are not predictive of dietary compliance. J Am Diet Assoc. 2004;104(1):35-41.

24. Brenner BM, Meyer TW, Hostetter TH. Dietary protein intake and the progressive nature of kidney disease: the role of hemodynamically mediated glomerular injury in the pathogenesis of progressive glomerular sclerosis in aging, renal ablation, and intrinsic renal disease. N Engl | Med. 1982;307(11):652-9.

25. Knight EL, Stampfer MI, Hankinson SE, Spiegelman D, Curhan GC. The impact of protein intake on renal function decline in women with normal renal function or mild renal insufficiency. Ann Intern Med. 2003;138(6):460-7.

26. Koppe $L$, Fouque $D$. The role for protein restriction in addition to renin-angiotensin-aldosterone system inhibitors in the management of CKD. Am J Kidney Dis. 2019;73(2):248-57.

27. Yan B, Su X, Xu B, Qiao X, Wang L. Effect of diet protein restriction on progression of chronic kidney disease: a systematic review and meta-analysis. PLoS One. 2018;13(11):e0206134.

28. NEPA - Núcleo de Estudos e Pesquisas em Alimentação. Tabela brasileira de composição de alimentos. 4a. ed. rev. Campinas: NEPA - UNICAMP; 2011. 161p.

29. Black AP, Anjos JS, Cardozo L, Carmo FL, Dolenga C), Nakao LS, et al. Does low-protein diet influence the uremic toxin serum levels from the gut microbiota in nondialysis chronic kidney disease patients? J Ren Nutr. 2018;28(3):208-14.

30. Marzocco S, Dal Piaz F, Di Micco L, Torraca S, Sirico ML, Tartaglia D, et al. Very low protein diet reduces indoxyl sulfate levels in chronic kidney disease. Blood Purif. 2013;35(1-3):196-201.

31. Cupisti A, Licitra R, Chisari C, Stampacchia G, D'Alessandro C, Galetta F, et al. Skeletal muscle and nutritional assessment in chronic renal failure patients on a protein-restricted diet. J Intern Med. 2004;255(1):115-24.

32. Haring B, Selvin E, Liang M, Coresh J, Grams ME, Petruski-Ivleva N, et al. Dietary protein sources and risk for incident chronic kidney disease: results from the Atherosclerosis Risk in Communities (ARIC) Study. J Ren Nutr. 2017;27(4):233-42.

33. Mirmiran P, Yuzbashian E, Aghayan M, Mahdavi M, Asghari G, Azizi F. A prospective study of dietary meat intake and risk of incident chronic kidney disease. J Ren Nutr. 2019. doi: 10.1053/j.jrn.2019.06.008.

34. Lew Q], Jafar TH, Koh HW, Jin A, Chow KY, Yuan IM, et al. Red meat intake and risk of ESRD. J Am Soc Nephrol. 2017;28(1):304-12.

35. Mello VD, Zelmanovitz T, Perassolo MS, Azevedo M|, Gross |L. Withdrawal of red meat from the usual diet reduces albuminuria and improves serum fatty acid profile in type 2 diabetes patients with macroalbuminuria. Am J Clin Nutr. 2006;83(5):1032-8.

36. Gross JL, Zelmanovitz T, Moulin CC, Mello V, Perassolo M, Leitão C, et al. Effect of a chicken-based diet on renal function and lipid profile in patients with type 2 diabetes: a randomized crossover trial. Diabetes Care. 2002;25(4):645-51.

37. ling Z, Wei-jie Y. Effects of soy protein containing isoflavones in patients with chronic kidney disease: a systematic review and meta-analysis. Clin Nutr. 2016;35(1):117-24.

38. Beto JA, Ramirez WE, Bansal VK. Medical nutrition therapy in adults with chronic kidney disease: integrating evidence and consensus into practice for the generalist registered dietitian nutritionist. J Acad Nutr Diet. 2014;114(7):1077-87

39. Koppe L, Cassani de Oliveira M, Fouque D. Ketoacid analogues supplementation in chronic kidney disease and future perspectives. Nutrients. 2019;11(9). doi: 10.3390/nu11092071.

40. Kistler BM, Benner D, Burrowes JD, Campbell KL, Fouque D, Garibotto G, et al. Eating during hemodialysis treatment: a consensus statement from the International Society of Renal Nutrition and Metabolism. J Ren Nutr. 2018;28(1):4-12.

41. Carvalho AB, Cuppari L. Controle da hiperfosfatemia na DRC. | Bras Nefrol. 2011;33(Suppl 1):S1-6.

42. Ramirez |A, Emmett M, White MG, Fathi N, Santa Ana CA, Morawski SG, et al. The absorption of dietary phosphorus and calcium in hemodialysis patients. Kidney Int. 1986;30(5):753-9.

43. Hernando N, Wagner CA. Mechanisms and regulation of intestinal phosphate absorption. Compr Physiol. 2018;8(3):1065-90.

44. Benini O, D'Alessandro C, Gianfaldoni D, Cupisti A. Extra-phosphate load 
from food additives in commonly eaten foods: a real and insidious danger for renal patients. J Ren Nutr. 2011;21(4):303-8.

45. Newsome B, IX JH, Tighiouart H, Sarnak MJ, Levey AS, Beck G], et al. Effect of protein restriction on serum and urine phosphate in the modification of diet in renal disease (MDRD) study. Am J Kidney Dis. 2013;61(6):1045-6.

46. Isakova T, Nickolas TL, Denburg M, Yarlagadda S, Weiner DE, Gutiérrez OM, et al. KDOQI US Commentary on the 2017 KDIGO Clinical Practice Guideline Update for the Diagnosis, Evaluation, Prevention, and Treatment of Chronic Kidney Disease-Mineral and Bone Disorder (CKD-MBD). Am J Kidney Dis. 2017;70(6):737-51.

47. Shinaberger CS, Greenland S, Kopple JD, Van Wyck D, Mehrotra R, Kovesdy $\mathrm{CP}$, et al. Is controlling phosphorus by decreasing dietary protein intake beneficial or harmful in persons with chronic kidney disease? Am I Clin Nutr. 2008;88(6):1511-8.

48. Noori N, Kalantar-Zadeh K, Kovesdy CP, Bross R, Benner D, Kopple JD. Association of dietary phosphorus intake and phosphorus to protein ratio with mortality in hemodialysis patients. Clin I Am Soc Nephrol. 2010;5(4):683-92

49. Brasil. Ministério da Saúde - MS. Agência Nacional de Vigilância Sanitária - ANVISA. Resolução RDC No 259, 20 de setembro de 2002. Aprova o Regulamento Técnico sobre Rotulagem de Alimentos Embalados. 2002.

50. León JB, Sullivan CM, Sehgal AR. The prevalence of phosphorus-containing food additives in top-selling foods in grocery stores. | Ren Nutr. 2013;23(4):265-70.

51. Fornasari ML, Santos Sens YA. Replacing phosphorus-containing food additives with foods without additives reduces phosphatemia in end-stage renal disease patients: a randomized clinical trial. J Ren Nutr. 2017;27(2):97-105.

52. Nerbass FB, Canzi ER, Araújo RA, Corrêa D, Santos RG, Vieira MA, et al Differences in phosphatemia and frequency of consumption of dietary sources of phosphorus in hemodialysis patients in southern and northern Brazil. J Bras Nefrol. 2019;41(1):157-8.

53. Palmer BF, Clegg DJ. Physiology and pathophysiology of potassium homeostasis. Adv Physiol Educ. 2016;40(4):480-90.

54. Goraya N, Simoni J, Jo C, Wesson DE. Dietary acid reduction with fruits and vegetables or bicarbonate attenuates kidney injury in patients with a moderately reduced glomerular filtration rate due to hypertensive nephropathy. Kidney Int. 2012;81(1):86-93.

55. Goraya N, Simoni J, Jo CH, Wesson DE. A comparison of treating metabolic acidosis in CKD stage 4 hypertensive kidney disease with fruits and vegetables or sodium bicarbonate. Clin J Am Soc Nephrol. 2013;8(3):371-81.

56. Cupisti A, Kovesdy CP, D'Alessandro C, Kalantar-Zadeh K. Dietary approach to recurrent or chronic hyperkalaemia in patients with decreased kidney function. Nutrients. 2018;10(3). doi: 10.3390/nu10030261.

57. Cuppari L, Amancio OMS, Nóbrega M, Sabbaga E. Preparo de vegetais para utilização em dieta restrita em potássio. Nutrire: Rev Soc Bras Alim Nutr. 2004;28:1-7.

58. Bethke PC, Jansky SH. The effects of boiling and leaching on the content of potassium and other minerals in potatoes. | Food Sci. 2008;73(5):H80-5.
59. Picard K. Potassium additives and bioavailability: are we missing something in hyperkalemia management? J Ren Nutr. 2019;29(4):350-3.

60. Sherman RA, Mehta O. Phosphorus and potassium content of enhanced meat and poultry products: implications for patients who receive dialysis. Clin J Am Soc Nephrol. 2009;4(8):1370-3.

61. Garofalo C, Borrelli S, Provenzano M, De Stefano T, Vita C, Chiodini P, et al. Dietary salt restriction in chronic kidney disease: a meta-analysis of randomized clinical trials. Nutrients. 2018;10(6). doi: 10.3390/nu10060732.

62. Vegter S, Perna A, Postma MJ, Navis G, Remuzzi G, Ruggenenti P. Sodium intake, ACE inhibition, and progression to ESRD. J Am Soc Nephrol. 2012;23(1):165-73.

63. Agondi RF, Gallani MC, Rodrigues RC, Cornélio ME. Relationship between beliefs regarding a low salt diet in chronic renal failure patients on dialysis. | Ren Nutr. 2011;21(2):160-8.

64. McLaren L, Sumar N, Barberio AM, Trieu K, Lorenzetti DL, Tarasuk V, et al. Population-level interventions in government jurisdictions for dietary sodium reduction. Cochrane Database Syst Rev. 2016;9:CD010166.

65. Monteiro CA, Moubarac |C, Cannon G, Ng SW, Popkin B. Ultra-processed products are becoming dominant in the global food system. Obes Rev. 2013;14(Suppl 2):21-8

66. Fiolet T, Srour B, Sellem L, Kesse-Guyot E, Allès B, Méjean C, et al. Consumption of ultra-processed foods and cancer risk: results from NutriNet-Santé prospective cohort. BMJ. 2018;360:k322.

67. Hall KD, Ayuketah A, Brychta R, Cai H, Cassimatis T, Chen KY, et al. Ultra-processed diets cause excess calorie intake and weight gain: an inpatient randomized controlled trial of ad libitum food intake. Cell Metab. 2019;30(1):67-77.

68. Heidemann C, Schulze MB, Franco OH, van Dam RM, Mantzoros CS, Hu FB. Dietary patterns and risk of mortality from cardiovascular disease, cancer, and all causes in a prospective cohort of women. Circulation. 2008;118(3):230-7.

69. Qian F, Liu G, Hu FB, Bhupathiraju SN, Sun Q. Association between plant-based dietary patterns and risk of type 2 diabetes: a systematic review and meta-analysis. JAMA Intern Med. 2019. doi: 10.1001/ jamainternmed.2019.2195.

70. Kim H, Caulfield LE, Rebholz CM. Healthy plant-based diets are associated with lower risk of all-cause mortality in US adults. J Nutr. 2018;148(4):624-31.

71. Satiia A, Bhupathiraju SN, Spiegelman D, Chiuve SE, Manson JE, Willett W, et al. Healthful and unhealthful plant-based diets and the risk of coronary heart disease in U.S. adults. J Am Coll Cardiol. 2017;70(4):411-22.

72. Willett W, Rockström J, Loken B, Springmann M, Lang T, Vermeulen S, et al. Food in the anthropocene: the EAT-Lancet Commission on healthy diets from sustainable food systems. Lancet. 2019;393(10170):447-92.

73. Kelly JT, Palmer SC, Wai SN, Ruospo M, Carrero IJ, Campbell KL, et al. Healthy dietary patterns and risk of mortality and ESRD in CKD: a meta-analysis of cohort studies. Clin J Am Soc Nephrol. 2017;12(2):272-9.

74. Wai SN, Kelly JT, Johnson DW, Campbell KL. Dietary patterns and clinical outcomes in chronic kidney disease: The CKD.QLD Nutrition Study. I Ren Nutr. 2017;27(3):175-82. 